\title{
Interactive effects of ocean acidification and nitrogen limitation on two bloom-forming dinoflagellate species
}

\author{
Tim Eberlein ${ }^{1}$, Dedmer B. Van de Waal ${ }^{1,2, *}$, Karen M. Brandenburg ${ }^{1,2}$, Uwe John ${ }^{1}$, \\ Maren Voss ${ }^{3}$, Eric P. Achterberg ${ }^{4}$, Björn Rost ${ }^{1}$
}

${ }^{1}$ Alfred Wegener Institute, Helmholtz Centre for Polar and Marine Research, Am Handelshafen 12, 27570 Bremerhaven, Germany

${ }^{2}$ Netherlands Institute of Ecology (NIOO-KNAW), PO Box 50, 6700 AB, Wageningen, The Netherlands

${ }^{3}$ Leibniz Institute for Baltic Sea Research Warnemünde, Seestrasse 15, 18119 Rostock, Germany

${ }^{4}$ GEOMAR Helmholtz Centre for Ocean Research, Wischhofstraße 1-3, 24148 Kiel, Germany

\begin{abstract}
Global climate change involves an increase in oceanic $\mathrm{CO}_{2}$ concentrations as well as thermal stratification of the water column, thereby reducing nutrient supply from deep to surface waters. Changes in inorganic carbon $(\mathrm{C})$ or nitrogen $(\mathrm{N})$ availability have been shown to affect marine primary production, yet little is known about their interactive effects. To test for these effects, we conducted continuous culture experiments under $\mathrm{N}$ limitation and exposed the bloomforming dinoflagellate species Scrippsiella trochoidea and Alexandrium fundyense (formerly A. tamarense) to $\mathrm{CO}_{2}$ partial pressures $\left(p \mathrm{CO}_{2}\right)$ ranging between 250 and $1000 \mu \mathrm{atm}$. Ratios of particulate organic carbon (POC) to organic nitrogen (PON) were elevated under $\mathrm{N}$ limitation, but also showed a decreasing trend with increasing $\mathrm{pCO}_{2}$. PON production rates were highest and affinities for dissolved inorganic $\mathrm{N}$ were lowest under elevated $p \mathrm{CO}_{2}$, and our data thus demonstrate a $\mathrm{CO}_{2}$-dependent trade-off in $\mathrm{N}$ assimilation. In A. fundyense, quotas of paralytic shellfish poisoning toxins were lowered under $\mathrm{N}$ limitation, but the offset to those obtained under N-replete conditions became smaller with increasing $\mathrm{pCO}_{2}$. Consequently, cellular toxicity under $\mathrm{N}$ limitation was highest under elevated $p \mathrm{CO}_{2}$. All in all, our observations imply reduced $\mathrm{N}$ stress under elevated $p \mathrm{CO}_{2}$, which we attribute to a reallocation of energy from $\mathrm{C}$ to $\mathrm{N}$ assimilation as a consequence of lowered costs in $\mathrm{C}$ acquisition. Such interactive effects of ocean acidification and nutrient limitation may favor species with adjustable carbon concentrating mechanisms and have consequences for their competitive success in a future ocean.
\end{abstract}

KEY WORDS: Dinoflagellates - Ocean acidification - Nitrogen limitation · Paralytic shellfish poisoning $\cdot$ PSP toxins

\section{INTRODUCTION}

Anthropogenic activities such as fossil fuel burning and changes in land use have caused atmospheric $\mathrm{CO}_{2}$ levels to rise at an unprecedented rate and concentrations are expected to approximately double from $400 \mu \mathrm{atm}$ at present to $900 \mu \mathrm{atm}$ by the year 2100 (RCP8.5 scenario; IPCC 2013). $\mathrm{CO}_{2}$ is taken up by the oceans and will shift the speciation of dis-

*Corresponding author: d.vandewaal@nioo.knaw.nl solved inorganic carbon, resulting in higher $\mathrm{CO}_{2}$ and $\mathrm{HCO}_{3}{ }^{-}$concentrations, lower $\mathrm{CO}_{3}{ }^{2-}$ concentrations, and an associated drop in $\mathrm{pH}$ by as much as 0.3 units for 2100 (i.e. ocean acidification; Caldeira \& Wickett 2003). Being a major greenhouse gas, $\mathrm{CO}_{2}$ also contributes to global warming, and sea surface temperatures are expected to rise by up to $4^{\circ} \mathrm{C}$ over the course of this century (RCP8.5 scenario; IPCC 2013). Consequently, thermal stratification of the water col-

() The authors 2016. Open Access under Creative Commons by Attribution Licence. Use, distribution and reproduction are unrestricted. Authors and original publication must be credited. 
umn may be enhanced, reducing the supply of nutrients from deep waters to the surface mixed layer, with likely consequences for primary production (Behrenfeld et al. 2006). Moreover, increasing temperatures may cause a shoaling of the surface mixed layer and thus enhance the mean irradiance phytoplankton experience over the day (Rost \& Riebesell 2004, Sarmiento et al. 2004).

In the past decades, numerous studies have described the effects of elevated $\mathrm{CO}_{2}$ partial pressure $\left(p \mathrm{CO}_{2}\right)$ on phytoplankton (Rost et al. 2008), but very few have investigated the combined effect with other variables such as temperature (e.g. Fu et al. 2007, 2008, Feng et al. 2008) or irradiance (e.g. Rokitta \& Rost 2012, Gao et al. 2013). This is surprising because nutrients, particularly nitrogen $(\mathrm{N})$, are considered key elements that limit primary production in large parts of the present-day ocean (Elser et al. 2007, Moore et al. 2013). The projected decrease in N supply to the upper mixed layer may be accompanied by lowered nitrification rates under ocean acidification, both leading to lower nitrate-supported primary production (Hutchins et al. 2009, Beman et al. 2011). In view of this and the fact that assimilation of carbon (C) and $\mathrm{N}$ are closely linked (Flynn 1991, Turpin 1991), it is particularly relevant to study the effects of elevated $p \mathrm{CO}_{2}$ under N-limiting conditions.

While the combined effects of elevated $p \mathrm{CO}_{2}$ and $\mathrm{N}$ limitation have been assessed in diatoms ( $\mathrm{Li}$ et al. 2012, Hennon et al. 2014) and coccolithophores (Sciandra et al. 2003, Rouco et al. 2013), dinoflagellates have so far been largely overlooked. Yet, they are expected to be highly sensitive to changes in $\mathrm{CO}_{2}$ availability due to their type II ribulose 1,5bisphosphate carboxylase/oxygenase (RuBisCO), which features low affinities for its substrate $\mathrm{CO}_{2}$ (Morse et al. 1995, Badger et al. 1998). Some dinoflagellate species express effective and adjustable carbon concentrating mechanisms (CCMs), which can prevent $\mathrm{CO}_{2}$ limitation in growth and primary production (Rost et al. 2006, Eberlein et al. 2014). In those studies, CCMs were shown to be down-regulated under elevated $p \mathrm{CO}_{2}$. Such a down-regulation could, in contrast to constitutively expressed CCMs, allow for a reallocation of energy to other cellular processes, e.g. the acquisition of limiting resources, an aspect that may be especially relevant under nutrient limitation.

Estuaries may promote coastal acidification even beyond the calculated $\mathrm{CO}_{2}$ projections for pelagic systems (Melzner et al. 2013, Wallace et al. 2014) and likely suffer from $\mathrm{N}$ limitation due to unbalanced nutrient loads. Dinoflagellates often proliferate in these eutrophic coastal waters, forming dense harmful algal blooms (HABs). HABs may not only have adverse effects on the ecosystem as result of high population densities, but their toxins also pose a direct threat to birds, fish, whales, and humans (Anderson et al. 2002, Granéli \& Turner 2006). The genus Alexandrium consists of many species that produce paralytic shellfish poisoning (PSP) toxins, which are potent neurotoxins that can accumulate in shellfish (Anderson et al. 2012a). PSP toxins are Nrich alkaloids with several analogues (Shimizu 1996, Cembella 1998, Anderson et al. 2012b), and their synthesis has been shown to depend on $\mathrm{N}$ availability (e.g. Boyer et al. 1987, Van de Waal et al. 2013, 2014b), but also on changes in $p \mathrm{CO}_{2}$ (Tatters et al. 2013, Van de Waal et al. 2014a, Hattenrath-Lehmann et al. 2015). Little is yet known about the combined effects of $\mathrm{N}$ limitation and elevated $p \mathrm{CO}_{2}$.

In order to improve our estimates about the responses of bloom-forming dinoflagellates to future changes, we investigated the combined effect of elevated $p \mathrm{CO}_{2}$ and $\mathrm{N}$ limitation on 2 dinoflagellate species, Scrippsiella trochoidea and Alexandrium fundyense (formerly A. tamarense; John et al. 2014). Both dinoflagellate species co-occur in the North Sea (Fistarol et al. 2004, McCollin et al. 2011) and while $S$. trochoidea has the ability to calcify, A. fundyense is a notorious PSP toxin producer, which may imply different strategies for $\mathrm{N}$ assimilation. By using a continuous culture system especially designed for dinoflagellates (Van de Waal et al. 2014c), we maintained both species under $\mathrm{N}$ limitation and studied the effects of increasing $\mathrm{CO}_{2}$ concentrations on growth, elemental composition and toxin content.

\section{MATERIALS AND METHODS}

\section{Experimental setup}

Scrippsiella trochoidea GeoB267 (culture collection of the University of Bremen) and Alexandrium fundyense (formerly A. tamarense strain Alex5; Tillmann et al. 2009), both originating from the North Sea, were cultured at $15^{\circ} \mathrm{C}$ in sterile-filtered North Sea water $(0.2 \mu \mathrm{m}$, salinity 34$)$. Vitamins and trace metals were added according to f/2 medium (Guillard \& Ryther 1962), except for $\mathrm{FeCl}_{3}\left(1.9 \mu \mathrm{mol} \mathrm{l}^{-1}\right)$, $\mathrm{H}_{2} \mathrm{SeO}_{3}\left(10 \mathrm{nmol} \mathrm{l}^{-1}\right)$ and $\mathrm{NiCl}_{2}\left(6.3 \mathrm{nmol} \mathrm{l}^{-1}\right)$. Phosphate was added to yield a final concentration of $6.25 \mu \mathrm{mol} \mathrm{l^{-1 }}$, whereas additions of nitrate differed between species, yielding final concentrations of 8 and $16 \mu \mathrm{mol} \mathrm{l}^{-1}$ for $S$. trochoidea and A. fundyense, 
respectively. Light was provided by daylight tubes (18W/965 Biolux, OSRAM) at a $16 \mathrm{~h}$ light:8 h dark cycle and adjusted to an incident photon flux density (PFD) of $250 \pm 30 \mu \mathrm{mol}$ photons $\mathrm{m}^{-2} \mathrm{~s}^{-1}$ using a spherical micro quantum sensor (Heinz Walz).

To maintain species under N-limiting conditions, a continuous culture system was applied (also referred to as chemostats). The advantage of this method is that at steady-state conditions, the consumption of $\mathrm{N}$ equals the supply rate of $\mathrm{N}$, and the growth rate is fixed by the dilution rate. Thus, continuous cultures allow controlled growth under N-limited conditions. In classical batch cultures, cells experience changing growth phases with an initial N-replete phase followed by N-limited and N-starved phases, which are accompanied by a decrease in growth rate. Growth characteristics (e.g. elemental quotas) thus consist of both $\mathrm{N}$-replete and $\mathrm{N}$-limited growth periods. In this study, we therefore applied a continuous culture system. This furthermore allowed comparison with previous studies that applied a dilute batch system (i.e. Eberlein et al. 2014, Van de Waal et al. 2014a) to obtain information on the responses under N-replete conditions with minimal changes in growth phases due to low population densities.

Species were grown in 2.11 continuous culture systems specially designed for dinoflagellates (for more details, see Van de Waal et al. 2014c). Homogeneous mixing was ensured by placing these vessels on a 3-dimensional orbital shaker (TL10, Edmund Bühler), set at an angle of $9^{\circ}$ with a shaking speed of $16 \mathrm{rpm}$, allowing a headspace and a polyoxymethylene ball to mix the system gently. Prior to the onset of the experiments, cells were acclimated for at least $1 \mathrm{wk}$ to the mixing system at ambient and elevated $p \mathrm{CO}_{2}$. High $p \mathrm{CO}_{2}$ was obtained by mixing $\mathrm{CO}_{2}$-free air $\quad<0.1 \mu$ atm $p \mathrm{CO}_{2}$ i Domnick Hunter) with pure $\mathrm{CO}_{2}$ (Air Liquide Deutschland) using mass flow controllers (CGM 2000, MCZ Umwelttechnik). $p \mathrm{CO}_{2}$ mixtures were regularly verified by measurements with a nondispersive infrared analyzer system (LI6252, LI-COR Biosciences). Initial $p \mathrm{CO}_{2}$ were achieved by aeration of the culture medium in the reservoir tanks, yielding values (mean $\pm \mathrm{SD}$ ) of between $428 \pm 96$ and $1224 \pm 90 \mu \mathrm{atm}$ for S. trochoidea, and $444 \pm 85$ and $829 \pm 96 \mu$ atm for A. fundyense. Owing to dilution-dependent exchange of culture medium, and dissolved inorganic carbon (DIC) drawdown during biomass build-up in the transition phase, steady-state $p \mathrm{CO}_{2}$ ranged from 300 to $800 \mu$ atm for $S$. trochoidea, and from 250 to 1000 patm for $A$. fundyense, which were grouped into $3 \mathrm{CO}_{2}$ treatments per species (Table 1).

To obtain steady-state population densities similar to those observed in dinoflagellate blooms (i.e. remaining below 1000 cells ml $^{-1}$; Wyatt \& Jenkinson 1997, Anderson et al. 2012b), the tested species required different dilution rates as well as different dissolved inorganic nitrogen (DIN) concentrations in the medium reservoir. Applied dilution rates yielded comparable growth limitation for the 2 species, i.e. $\sim 33 \%$ of their maximum growth rate. More specifically, $S$. trochoidea was grown at $0.2 \pm 0.01 \mathrm{~d}^{-1}$ and $8 \mu \mathrm{mol} \mathrm{l}^{-1}$ DIN, while $A$. fundyense was set to $0.15 \pm$ $0.01 \mathrm{~d}^{-1}$ and $16 \mu \mathrm{mol} \mathrm{l} \mathrm{l}^{-1}$ DIN. These differences in initial DIN concentrations have no effect on $\mathrm{pH}$ or $p \mathrm{CO}_{2}$. Every 2 to $3 \mathrm{~d}$ and 5 to $7 \mathrm{~h}$ after the start of the light period, samples were taken to determine population densities, carbonate chemistry and residual DIN concentrations. Continuous culture systems that were exposed to elevated $p \mathrm{CO}_{2}$ generally required a longer time period to establish a steady state than those under ambient $p \mathrm{CO}_{2}$. For this reason, transition phases ranged from 22 to $42 \mathrm{~d}$. The carbonate chemistry parameters presented in Table 1 relate to the steady-state conditions after the transition phase of 6 individual continuous culture experiments per species, grouped into the $3 \mathrm{CO}_{2}$ treatments. Values in Table 1 thus represent means and data ranges based

Table 1. Carbonate chemistry for the different continuous culture experiments. Mean values of $\mathrm{pCO}_{2}$ and respective data range (minimum and maximum) were calculated based on dissolved inorganic carbon (DIC) and $\mathrm{pH}$ values during steady state using $\mathrm{CO}_{2}$ Sys (Pierrot et al. 2006). $\mathrm{pH}$ values are given on the NBS scale $\left(\mathrm{pH}_{\mathrm{NBS}}\right)$. Total alkalinity (TA) values indicate the mean of values obtained at the beginning and the end of each continuous culture experiment

\begin{tabular}{|c|c|c|c|c|}
\hline $\begin{array}{l}\mathrm{CO}_{2} \text { treat- } \\
\text { ment ( } \mu \mathrm{atm})\end{array}$ & $\begin{array}{c}p \mathrm{CO}_{2} \\
(\mu \mathrm{atm})\end{array}$ & $\begin{array}{c}\text { TA } \\
\left(\mu \mathrm{mol} \mathrm{l^{-1 }}\right)\end{array}$ & $\begin{array}{c}\text { DIC } \\
\left(\mu \mathrm{mol} \mathrm{l}^{-1}\right)\end{array}$ & $\mathrm{pH}_{\mathrm{NBS}}$ \\
\hline \multicolumn{5}{|c|}{ Scrippsiella trochoidea } \\
\hline 300 & $\begin{array}{c}298 \\
(259-337)\end{array}$ & $\begin{array}{c}2349 \\
(2305-2385)\end{array}$ & $\begin{array}{c}2148 \\
(2141-2161)\end{array}$ & $\begin{array}{c}8.31 \\
(8.25-8.36)\end{array}$ \\
\hline 600 & $\begin{array}{c}601 \\
(572-650)\end{array}$ & $\begin{array}{c}2389 \\
(2367-2405)\end{array}$ & $\begin{array}{c}2230 \\
(2205-2235)\end{array}$ & $\begin{array}{c}8.03 \\
(8.00-8.06)\end{array}$ \\
\hline 800 & $\begin{array}{c}793 \\
(742-855)\end{array}$ & $\begin{array}{c}2365 \\
(2357-2373)\end{array}$ & $\begin{array}{c}2252 \\
(2241-2265)\end{array}$ & $\begin{array}{c}7.92 \\
(7.89-7.95)\end{array}$ \\
\hline \multicolumn{5}{|c|}{ Alexandrium fundyense } \\
\hline 250 & $\begin{array}{c}237 \\
(220-258)\end{array}$ & $\begin{array}{c}2372 \\
(2336-2392)\end{array}$ & $\begin{array}{c}2097 \\
(2077-2122)\end{array}$ & $\begin{array}{c}8.39 \\
(8.36-8.41)\end{array}$ \\
\hline 800 & $\begin{array}{c}813 \\
(727-937)\end{array}$ & $\begin{array}{c}2398 \\
(2392-2405)\end{array}$ & $\begin{array}{c}2252 \\
(2240-2271)\end{array}$ & $\begin{array}{c}7.91 \\
(7.90-7.96)\end{array}$ \\
\hline 1000 & $\begin{array}{c}1018 \\
(918-1154)\end{array}$ & $\begin{array}{c}2397 \\
(2392-2407)\end{array}$ & $\begin{array}{c}2272 \\
(2263-2291)\end{array}$ & $\begin{array}{c}7.82 \\
(7.77-7.86)\end{array}$ \\
\hline
\end{tabular}


Table 2. Responses of Scrippsiella trochoidea and Alexandrium fundyense grown under N-limited conditions and different $p \mathrm{CO}_{2}\left(\mathrm{CO}_{2}\right.$ treatment). Values for particulate organic carbon (POC):particulate organic nitrogen (PON) ratios, $\mathrm{POC}, \mathrm{PON}$, and $\mathrm{chl} a$ show the biological mean of replicates $(\mathrm{n}=2)$ and data range (minimum and maximum)

\begin{tabular}{|c|c|c|c|c|c|c|}
\hline $\begin{array}{l}\mathrm{CO}_{2} \text { treatment } \\
(\mu \mathrm{atm})\end{array}$ & $\begin{array}{l}\text { POC:PON } \\
\text { (molar) }\end{array}$ & $\begin{array}{c}\text { POC } \\
\left(\text { ng cell }^{-1}\right)\end{array}$ & $\begin{array}{c}\text { PON } \\
\left(\mathrm{ng} \mathrm{cell}^{-1}\right)\end{array}$ & $\begin{array}{c}\text { Chl a } \\
\left(\text { pg cell }{ }^{-1}\right)\end{array}$ & $\begin{array}{l}\text { POC:chl a } \\
\text { (mass) }\end{array}$ & $\begin{array}{c}\text { Volume } \\
\left(\mu \mathrm{m}^{3} \text { cell }^{-1}\right)\end{array}$ \\
\hline \multicolumn{7}{|l|}{ S. trochoidea } \\
\hline 300 & $\begin{array}{c}21.34 \\
(20.33-22.34)\end{array}$ & $\begin{array}{c}4.29 \\
(4.15-4.43)\end{array}$ & $\begin{array}{c}0.24 \\
(0.23-0.24)\end{array}$ & $\begin{array}{c}8.99 \\
(7.84-10.14)\end{array}$ & $\begin{array}{c}489 \\
(419-558)\end{array}$ & $\begin{array}{c}9204 \\
(8933-9475)\end{array}$ \\
\hline 600 & $\begin{array}{c}24.71 \\
(24.26-25.15)\end{array}$ & $\begin{array}{c}4.24 \\
(4.07-4.4)\end{array}$ & $\begin{array}{c}0.20 \\
(0.19-0.21)\end{array}$ & $\begin{array}{c}9.20 \\
(8.77-9.63)\end{array}$ & $\begin{array}{c}464 \\
(454-474)\end{array}$ & $\begin{array}{c}7959 \\
(7690-8227)\end{array}$ \\
\hline 800 & $\begin{array}{c}18.01 \\
(17.27-18.74)\end{array}$ & $\begin{array}{c}4.07 \\
(3.84-4.29)\end{array}$ & $\begin{array}{c}0.27 \\
(0.26-0.27)\end{array}$ & $\begin{array}{c}11.18 \\
(10.59-11.76)\end{array}$ & $\begin{array}{c}369 \\
(330-407)\end{array}$ & $\begin{array}{c}12046 \\
(11780-12311)\end{array}$ \\
\hline \multicolumn{7}{|l|}{ A. fundyense } \\
\hline 250 & $\begin{array}{c}9.53 \\
(9.23-9.82)\end{array}$ & $\begin{array}{c}3.93 \\
(3.9-3.96)\end{array}$ & $\begin{array}{c}0.48 \\
(0.46-0.5)\end{array}$ & $\begin{array}{c}22.92 \\
(21.22-24.62)\end{array}$ & $\begin{array}{c}173 \\
(161-184)\end{array}$ & $\begin{array}{c}17496 \\
(16 \text { 699-18 293) }\end{array}$ \\
\hline 800 & $\begin{array}{c}6.75 \\
(6.68-6.82)\end{array}$ & $\begin{array}{c}2.71 \\
(2.68-2.74)\end{array}$ & $\begin{array}{c}0.47 \\
(0.47-0.47)\end{array}$ & $\begin{array}{c}24.66 \\
(24.6-24.71)\end{array}$ & $\begin{array}{c}106 \\
(100-111)\end{array}$ & $\begin{array}{c}15591 \\
(14533-16 \text { 649) }\end{array}$ \\
\hline 1000 & $\begin{array}{c}5.77 \\
(5.5-6.04)\end{array}$ & $\begin{array}{c}3.55 \\
(3.43-3.66)\end{array}$ & $\begin{array}{c}0.72 \\
(0.71-0.73)\end{array}$ & $\begin{array}{c}33.05 \\
(31.34-34.75)\end{array}$ & $\begin{array}{c}108 \\
(99-117)\end{array}$ & $\begin{array}{c}17658 \\
(16279-19036)\end{array}$ \\
\hline
\end{tabular}

on 4 consecutive sampling points during steady state, while values in Table 2 represent means and data ranges based on mean steady-state values of 2 biological replicates for each treatment.

\section{Sampling and analysis}

To determine population densities, cell samples were fixed with Lugol's solution (1\% final concentration) and counted in duplicates (during the experiment) or triplicates (at the end of each experiment) with an Axiovert 40C inverted microscope (Carl Zeiss MicroImaging $\mathrm{GmbH}$ ). Size measurements (i.e. for calculating biovolume) were performed with the same microscope using the AxioCam MRc5 (software SE64 Rel. 4.8, Carl Zeiss MicroImaging $\mathrm{GmbH}$ ), and all values represent the mean \pm SD of at least 50 cells.

The $\mathrm{pH}$ was measured with a 3 -point calibrated $\mathrm{pH}$ meter (826 pH mobile, Metrohm). Duplicate DIC samples were analyzed in a QuAAtro high performance microflow analyzer (Seal Analytical) with a mean precision of $8 \mu \mathrm{mol} \mathrm{l}^{-1}$. Samples for total alkalinity (TA) were taken at the beginning and the end of each experiment $(\mathrm{n}=2)$ and analyzed by a fully automated titration system (SI Analytics) with a mean precision of $13 \mu \mathrm{mol} \mathrm{l^{-1 }}$. Certified Reference Materials supplied by A. G. Dickson (Scripps Institution of Oceanography) were used to correct for inaccuracies in TA and DIC measurements. Subsequently, carbonate chemistry was calculated with $\mathrm{CO}_{2}$ Sys (Pierrot et al. 2006) using $\mathrm{pH}_{\mathrm{NBS}}$ (National Bureau of Standards) and DIC with equilibrium constants of Mehrbach et al. (1973), refitted by Dickson \& Millero (1987).

The residual DIN concentrations, i.e. nitrate $\left(\mathrm{NO}_{3}{ }^{-}\right)$ and nitrite $\left(\mathrm{NO}_{2}^{-}\right)$, in the continuous culture systems were determined in sterile-filtered culture medium $(0.2 \mu \mathrm{m})$, which was stored at $-20^{\circ} \mathrm{C}$ in acid-washed tubes prior to analysis. Samples were analyzed through a custom-made nanomolar nutrient system (Ocean Optics). The system comprised a $2 \mathrm{~m}$ liquid waveguide capillary cell (World Precision Instruments) with a tungsten halogen light source (LS1-LL, Ocean Optics) and a miniaturized spectrophotometer (USB2000 VIS-NIR, Ocean Optics). Samples were introduced to the system via a conventional segmented-flow autoanalyzer. Prior to determination of DIN, $\mathrm{NO}_{3}{ }^{-}$was reduced to $\mathrm{NO}_{2}{ }^{-}$using a copperized cadmium column and all $\mathrm{NO}_{2}{ }^{-}$was spectrophotometrically detected at $540 \mathrm{~nm}$ following the sulphanilamide and N-(1-Naphthyl)-ethylenediamine (NED) reaction. For more details on the method see Patey et al. (2008).

Cultures were kept for $>5 \mathrm{~d}$ in steady-state conditions (also referred to as equilibrium-state), during which population densities and carbonate chemistry remained largely constant (Table 1). Therefore, potential carry-over effects from the initial conditions are assumed to be negligible. At the end of this steady-state period, experiments were stopped and samples were taken to assess particulate organic carbon (POC) and nitrogen (PON), chlorophyll a (chl a); and for PSP toxins, in the case of A. fundyense. 
For determination of POC and PON, culture suspension was filtered in triplicate on pre-combusted $\mathrm{GF} / \mathrm{F}$ filters $\left(500^{\circ} \mathrm{C}, 6 \mathrm{~h}\right.$; Whatman). To remove potential inorganic carbon retained on the filter, $200 \mu \mathrm{HCl}$ $\left(0.2 \mathrm{~mol} \mathrm{l}^{-1}\right)$ was added to each sample. Filters were dried at $60^{\circ} \mathrm{C}$ in a drying oven for at least $24 \mathrm{~h}$. The filters were then packed into tin cups, pressed into pellets and measured with a Delta $\mathrm{S}$ isotopic ratio mass spectrometer (Thermo) connected to an elemental analyzer CE1108 via an open split interface (Conflow II, Thermo). The reference gases were ultra-high purity $\mathrm{N}_{2}$ and $\mathrm{CO}_{2}$ from a gas cylinder calibrated against standards from the International Atomic Energy Agency (IAEA N1, N2, N3, C3, C6, and NBS 22). Acetanilid and Peptone (Merck Millipore) served as lab-internal elemental and isotope standards for daily calibration.

To determine chl $a$, culture medium was filtered in duplicate on $0.45 \mu \mathrm{m}$ cellulose-nitrate membrane filters (Whatman), rapidly frozen in liquid nitrogen and subsequently stored at $-80^{\circ} \mathrm{C}$. Extraction and fluorometric determination of $\mathrm{chl}$ a were performed in accordance with Knap et al. (1996) using a TD-700 Fluorometer (Turner Designs).

To determine the predominant PSP toxin analogues of $A$. fundyense, including the non-sulfated saxitoxin (STX) and neosaxitoxin (NEO), the mono-sulfated gonyautoxins (GTX 1-4), and the di-sulfated C-toxins $(\mathrm{C} 1+\mathrm{C} 2)$, culture samples were filtered in duplicate over polycarbonate filters (1.0 $\mu \mathrm{m}$ pore size; Whatman) and stored in Eppendorf tubes at $-20^{\circ} \mathrm{C}$. Toxins were extracted following the method of Van de Waal et al. (2014a) and analyzed in accordance with Krock et al. (2007). Cellular toxicity was estimated from the cellular PSP content and the relative toxicity of each PSP toxin analogue (Wiese et al. 2010).

\section{Statistics and error propagation}

For every parameter, various statistical models were applied (linear and exponential regression, Gaussian peak) to test for correlations with $p \mathrm{CO}_{2}$, using the 6 biological replicates for the continuous culture experiments (this study), and 12 biological replicates of the dilute batch experiments (Eberlein et al. 2014, Van de Waal et al. 2014a). The 3-parameter models were tested against 2-parameter models using the Akaike information criterion (AIC; Rawlings et al. 1998). The 2-parameter models were tested against each other on the basis of the coefficient of determination $\left(\mathrm{R}^{2}\right)$. The best fit is quoted in the text.
Linear regression model:

$$
y(x)=y_{0}+a x
$$

where $y_{0}$ is the $y$-intercept and a represents the slope.

The 2-parameter exponential regression model:

$$
y(t)=y_{0} \mathrm{e}^{b t}
$$

where $y_{0}$ is the initial quantity, $b$ represents the growth rate and $t$ is time in days. When applying an exponential decay model, $b$ is negative.

Gaussian peak regression model:

$$
y(x)=a^{\left(-\frac{(x-b)^{2}}{2 c^{2}}\right)}
$$

where $a$ is the height, $b$ is the location of the centroid and $c$ represents the width.

As our results suggested a non-linear relationship between PSP toxin content and POC:PON ratios, we applied a 3-parameter exponential decay model and determined the minimum cellular toxin content:

$$
\mathrm{PSP}_{\min }=\mathrm{PSP}-y_{0} \mathrm{e}^{-b(\mathrm{POC}: \mathrm{PON})}
$$

where PSP and $\mathrm{PSP}_{\min }$ are the measured and minimum PSP toxin content, respectively.

Half-saturation concentrations $\left(K_{1 / 2}\right)$ for growth were calculated based on Monod (1949), according to:

$$
K_{1 / 2}=\frac{R \mu_{\max }}{\mu_{\text {limited }}}-R
$$

where $\mu_{\max }$ was taken from $\mathrm{N}$-replete experiments (Eberlein et al. 2014), $\mu_{\text {limited }}$ represents growth rates in the continuous culture system (equal to the dilution rate), and $R$ is the residual DIN concentration (often referred to as the lowest resource requirement, i.e. $R^{*}$ ). Propagation of uncertainties was calculated using the law of combination of errors (e.g. Barlow 1989).

For testing interactive effects of $\mathrm{CO}_{2}$ and $\mathrm{N}$ availability on PSP toxin content, toxicity, and toxin composition, we applied analysis of covariance (ANCOVA). In case the assumption of homogeneity of regression slopes was violated, we performed the Johnson-Neyman technique (Johnson \& Neyman 1936). We defined the range of significant differences using the software IBM SPSS Statistics, version 12 (Hayes \& Matthes 2009). Normality and homogeneity of PSP toxin content, toxicity, and composition were confirmed by applying the Shapiro-Wilks and Levene's test, respectively. Variables were log-transformed if this improved the equality of variables. The threshold significance level $(\alpha)$ in all tests was set at 0.05 . 


\section{RESULTS}

\section{Growth characteristics}

For both tested species, population densities at the start of the continuous culture experiments ranged from 10 to 70 cells $\mathrm{ml}^{-1}$. These low initial population densities and the initially high DIN concentrations allowed for maximum growth rates, which were $0.48 \pm 0.05$ and $0.41 \pm 0.03 \mathrm{~d}^{-1}$ for Scrippsiella trochoidea and Alexandrium fundyense, respectively. In the course of biomass build-up, DIN concentrations decreased and cultures grew into $\mathrm{N}$ limitation. Here, growth rates were lowered and population densities in the continuous culture experiments stabilized, reaching a steady-state. Under these conditions, growth rates resembled the dilution rates of 0.2 \pm 0.01 and $0.15 \pm 0.01 \mathrm{~d}^{-1}$ for $S$. trochoidea and $A$.

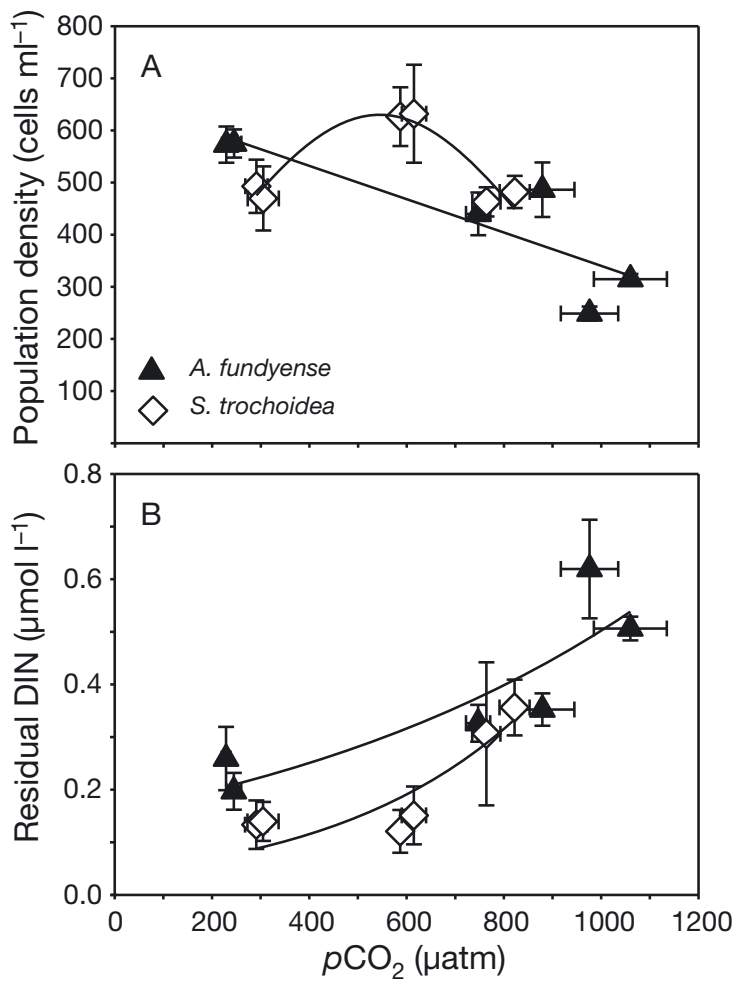

Fig. 1. Effects of elevated $p \mathrm{CO}_{2}$ under $\mathrm{N}$ limitation on (A) population densities and (B) residual dissolved inorganic nitrogen (DIN) concentrations for Scrippsiella trochoidea ( $)$ and Alexandrium fundyense ( $(\mathbf{\Delta})$. Symbols indicate the mean \pm SD of replicates over time from each steady state $(n \geq 4)$. Solid lines indicate significant trends and the best fits from the tested regression models: (A) S. trochoidea, Gaussian peak regression model: $\mathrm{R}^{2}=0.87, \mathrm{n}=6, \mathrm{p}=0.049 ; A$. fundyense, linear regression model: $\mathrm{R}^{2}=0.76, \mathrm{n}=6, \mathrm{p}=$ 0.024. (B) $S$. trochoidea, exponential regression model: $\mathrm{R}^{2}=$ $0.78, \mathrm{n}=6, \mathrm{p}=0.020 ; A$. fundyense, exponential regression model: $\mathrm{R}^{2}=0.75, \mathrm{n}=6, \mathrm{p}=0.025$ fundyense, respectively. Steady-state $p \mathrm{CO}_{2}$ ranged from about 300 to $800 \mu$ atm for $S$. trochoidea and 250 to $1000 \mu \mathrm{atm}$ for $A$. fundyense, which were grouped into $3 \mathrm{CO}_{2}$ treatments per species (Table 1).

Population densities during steady state differed between $p \mathrm{CO}_{2}$ treatments of both species (Fig. 1A). Densities of $S$. trochoidea showed a bell-shaped pattern, being highest at intermediate $p \mathrm{CO}_{2}$ with $\sim 630$ cells $\mathrm{ml}^{-1}$, and similarly low in the low and high $p \mathrm{CO}_{2}$ treatments with $\sim 45$ cells ml $^{-1}$ (Fig. 1A). In $A$. fundyense, cell densities decreased with increasing $p \mathrm{CO}_{2}$ from $\sim 570$ cells $\mathrm{ml}^{-1}$ at low $p \mathrm{CO}_{2}$ towards 280 cells $\mathrm{ml}^{-}$at the highest $p \mathrm{CO}_{2}$ (Fig. 1A). The observed decrease in densities was stronger between intermediate and high, than between low and intermediate $p \mathrm{CO}_{2}$.

Residual DIN concentrations during steady state were reduced to values below $1 \mu \mathrm{mol} \mathrm{l}^{-1}$ for both species. In $S$. trochoidea, lowest DIN concentrations of $137 \pm 46 \mathrm{nmol} \mathrm{l}^{-1}$ were observed at low and intermediate $p \mathrm{CO}_{2}$, while they increased to $330 \pm 105 \mathrm{nmol}$ $1^{-1}$ in the high $p \mathrm{CO}_{2}$ treatment (Fig. 1B). Increasing residual DIN concentrations under elevated $p \mathrm{CO}_{2}$ were also observed for $A$. fundyense, as they increased from $227 \pm 62 \mathrm{nmol}^{-1}$ at low $p \mathrm{CO}_{2}$ towards $549 \pm 79 \mathrm{nmol} \mathrm{l}^{-1}$ at high $p \mathrm{CO}_{2}$ (Fig. 1B).

\section{Elemental composition}

Here we present elemental composition and PSP toxin data of N-limited $S$. trochoidea and $A$. fundyense cultures exposed to a range of $\mathrm{pCO}_{2}$ (this study), which are compared with data obtained under N-replete conditions (Eberlein et al. 2014, Van de Waal et al. 2014a). Consequently, we can assess the effect of $\mathrm{N}$ availability on $\mathrm{CO}_{2}$ responses.

Under $\mathrm{N}$ limitation, the cellular POC:PON ratios of $S$. trochoidea were generally high and ranged between 17 and 25, showing maximum values in the intermediate, and lowest values in the high $p \mathrm{CO}_{2}$ treatment (Table 2; Gaussian peak model: $\mathrm{R}^{2}=0.92$, $\mathrm{n}=6, \mathrm{p}=0.022$ ). In comparison to N-replete conditions, the observed ratios were more than 2-fold higher (Table 2; cf. Eberlein et al. 2014). In $A$. fundyense, POC:PON ratios under $\mathrm{N}$ limitation decreased from about 10 to 6 in the low to the high $p \mathrm{CO}_{2}$ treatment (Table 2; linear regression model: $\left.\mathrm{R}^{2}=0.94, \mathrm{n}=6, \mathrm{p}=0.001\right)$, and thereby reached values similar to N-replete conditions (Table 2; cf. Eberlein et al. 2014).

For both species, the decrease in POC:PON ratios under elevated $p \mathrm{CO}_{2}$ was accompanied by an in- 
crease in residual DIN concentrations, resulting in lowest POC:PON ratios at highest residual DIN concentrations (Table 2). The high POC:PON ratios in $S$. trochoidea reflected 2-fold increased POC quotas under $\mathrm{N}$ limitation, while PON quotas remained largely unaltered (Table 2; cf. Eberlein et al. 2014). The changes in POC:PON ratios under elevated $p \mathrm{CO}_{2}$, however, resulted from alterations in PON quotas, which were highest in the high $p \mathrm{CO}_{2}$ treatment (Table 2). In A. fundyense, POC:PON ratios decreased with increasing $p \mathrm{CO}_{2}$, reflecting both a change in POC as well as in PON quotas. More specifically, PON quotas were highest in the high $p \mathrm{CO}_{2}$ treatment and POC quotas were lowest in the intermediate $p \mathrm{CO}_{2}$ treatment (Table 2). POC quotas largely resembled those under $\mathrm{N}$-replete conditions, while PON quotas were generally lower, except for the highest $p \mathrm{CO}_{2}$ treatment where PON quotas were similar (Table 2; cf. Eberlein et al. 2014).

In both tested species, chl a quotas increased under elevated $p \mathrm{CO}_{2}$ (Table 2). In $S$. trochoidea, values under $\mathrm{N}$ limitation were generally higher as compared to those under N-replete conditions, whereas in $A$. fundyense values were lower and approximated those under $\mathrm{N}$-replete conditions at high $p \mathrm{CO}_{2}$ (Table 2; cf. Eberlein et al. 2014). Cell volumes of $S$. trochoidea and A. fundyense remained largely unaffected by elevated $p \mathrm{CO}_{2}$ (Table 2). For $S$. trochoidea, however, cell volumes were higher under $\mathrm{N}$ limitation compared to those under N-replete conditions $\left(\sim 5000 \mathrm{\mu m}^{3}\right.$ cell $\left.^{-1}\right)$. Calcification in $S$. trochoidea was very low with PIC:POC ratios $<0.1$ in all $p \mathrm{CO}_{2}$ treatments, irrespective of $\mathrm{N}$ availability (data not shown).

\section{PSP toxin content and composition in A. fundyense}

Under $\mathrm{N}$ limitation, cellular PSP toxin content increased over the applied range of $p \mathrm{CO}_{2}$ (Fig. 2A), which can be attributed to a general increase in all PSP toxin analogues. In the high $p \mathrm{CO}_{2}$ treatment, total PSP toxin content was close to values observed under N-replete conditions, reaching above $70 \mathrm{pg}$ cell $^{-1}$ compared to about $80 \mathrm{pg}$ cell $^{-1}$, respectively. Cellular toxicity largely followed these changes in toxin content and increased with elevated $\mathrm{pCO}_{2}$ towards 48 pg STX equivalents (STXeq) $\mathrm{cell}^{-1} \mathrm{com}$ pared to $47 \mathrm{pg}^{\mathrm{STX}} \mathrm{eq} \mathrm{cell}^{-1}$ under N-replete conditions (Fig. 2B).

The contribution of STX relative to total PSP toxin content increased under elevated $p \mathrm{CO}_{2}$ (Fig. 3A), while the relative contribution of GTX1+4 decreased

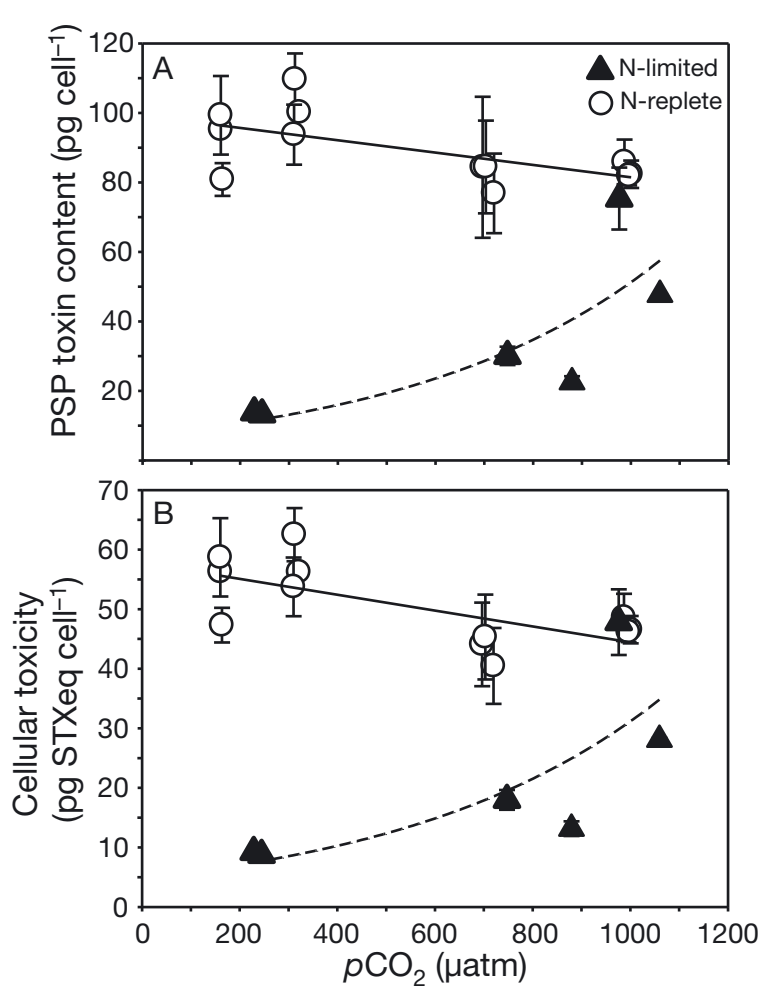

Fig. 2. Effect of elevated $p \mathrm{CO}_{2}$ on (A) paralytic shellfish poisoning (PSP) toxin content and (B) cellular toxicity in saxitoxin equivalents (STXeq) for Alexandrium fundyense under N-limiting $(\boldsymbol{\Lambda}$, this study) and $\mathrm{N}$-replete $(\mathrm{O}$, Van de Waal et al. 2014a) conditions. Symbols indicate the mean \pm $\mathrm{SD}$ of technical replicates $(\mathrm{n}=2)$. Solid (significant trend) and dashed (non-significant trend) lines indicate the best fits of tested regression models. (A) N-limited, exponential regression model: $\mathrm{R}^{2}=0.61, \mathrm{n}=6, \mathrm{p}=0.242$; N-replete, linear regression model: $R^{2}=0.37, n=12, p=0.036$. (B) N-limited, exponential regression model: $\mathrm{R}^{2}=0.55, \mathrm{n}=6, \mathrm{p}=$ 0.303; N-replete, linear regression model: $\mathrm{R}^{2}=0.45, \mathrm{n}=12$, $\mathrm{p}=0.018$

(Fig. 3B), displaying opposite patterns as observed under N-replete conditions (Fig. 3A,B). Significantly higher contributions of GTX1+4 under N-limited compared to $\mathrm{N}$-replete conditions were recorded over almost the entire range of applied $p \mathrm{CO}_{2}$, while contributions of STX were lower under N-limited compared to $\mathrm{N}$-replete conditions (Johnson-Neyman: $\mathrm{p}<0.05)$. The relative contribution of $\mathrm{C} 1+\mathrm{C} 2$ to total PSP toxin content increased under elevated $p \mathrm{CO}_{2}$ (Fig. 3C), displaying a similar trend as under $\mathrm{N}-$ replete conditions (Fig. 3C). Contributions of $\mathrm{C} 1+\mathrm{C} 2$ were, however, significantly lower under N-limited conditions at a $\mathrm{pCO}_{2}$ higher than $200 \mu$ atm (JohnsonNeyman: $\mathrm{p}<0.05$ ). Relative contributions of NEO and GTX2+3 remained largely unaltered over the applied range of $p \mathrm{CO}_{2}$ and were comparable to those under N-replete conditions (Fig. 3D,E). The $\mathrm{CO}_{2}$ - 


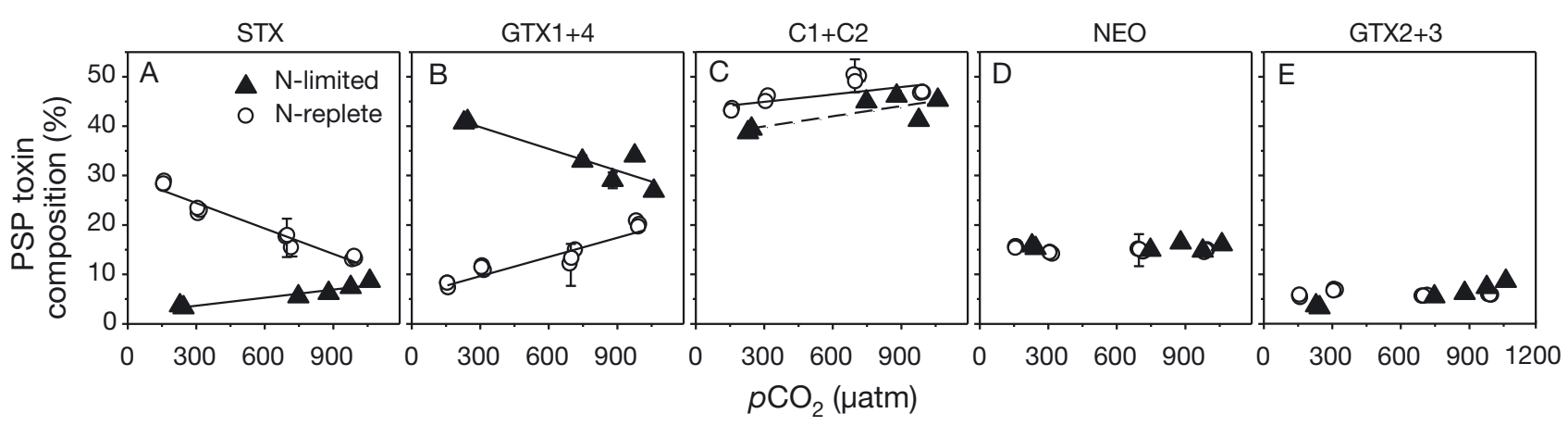

Fig. 3. (A-E) Effect of elevated $p \mathrm{CO}_{2}$ on PSP toxin composition in Alexandrium fundyense under N-limiting ( $\mathbf{\Lambda}$, this study) and N-replete (O, Van de Waal et al. 2014a) conditions. STX: saxitoxins; GTX: gonyautoxins; C1+C2: C-toxins; NEO: neosaxitoxins. Symbols indicate the mean $\pm \mathrm{SD}$ of technical replicates $(\mathrm{n}=2)$. Solid (significant trend) and dashed (non-significant trend) lines indicate the best fits of tested regression models. (A) N-limited, linear regression model: $R^{2}=0.92, n=6, p=0.002$; N-replete, linear regression model: $\mathrm{R}^{2}=0.95, \mathrm{n}=12, \mathrm{p}<0.001$. (B) N-limited, linear regression model: $\mathrm{R}^{2}=0.85, \mathrm{n}=6, \mathrm{p}=$ 0.009; N-replete, linear regression model: $R^{2}=0.90, n=12, p<0.001 ;(C)$ N-limited, linear regression model: $R^{2}=0.60, n=6$, $\mathrm{p}=0.069 ;$ N-replete, linear regression model: $\mathrm{R}^{2}=0.46, \mathrm{n}=12, \mathrm{p}=0.015$

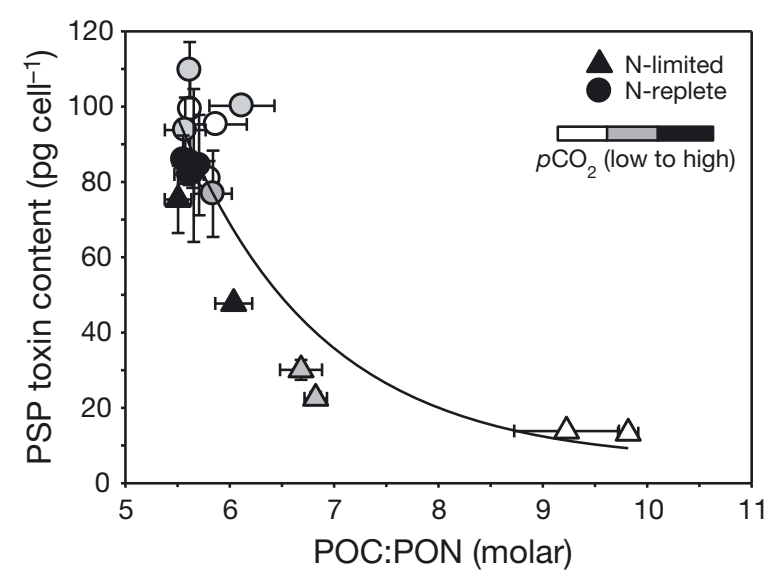

Fig. 4. Effect of elevated $p \mathrm{CO}_{2}$ on PSP toxin content versus particulate organic carbon (POC): particulate organic nitrogen (PON) ratios in Alexandrium fundyense under N-limited $(\boldsymbol{\Lambda}$, this study) and N-replete conditions $(\bullet$, Van de Waal et al. 2014a). Symbols indicate the mean \pm SD of technical replicates $(n=2)$. Solid line indicates the significant trend and best fit from a 3-parameter exponential decay model $\left(\mathrm{R}^{2}=0.77, \mathrm{n}=18, \mathrm{p}<0.001\right)$

dependent increase in toxin content under N-limited conditions was accompanied by a decrease in the POC:PON ratio (Fig. 4), so that both PSP toxin content and POC:PON ratios were comparable to the Nreplete conditions under elevated $p \mathrm{CO}_{2}$.

\section{DISCUSSION}

Although various experiments have investigated the responses of dinoflagellates under elevated $p \mathrm{CO}_{2}$ (e.g. Rost et al. 2006, Fu et al. 2008, Brading et al.
2013) or N limitation (e.g. Leong \& Taguchi 2004, Collos et al. 2005, Van de Waal et al. 2013), this study is, to our knowledge, the first to look at the combined effects in this phytoplankton group. Using a continuous culturing system especially designed for dinoflagellates (Van de Waal et al. 2014c) allowed us to maintain cultures of Scrippsiella trochoidea and Alexandrium fundyense under $\mathrm{N}$ limitation while studying their responses to elevated $p \mathrm{CO}_{2}$. By comparing our results with recent work on the same strains under $\mathrm{N}$-replete conditions (Eberlein et al. 2014, Van de Waal et al. 2014a), we were then able to describe the effect of $\mathrm{N}$ availability on $\mathrm{CO}_{2}$ responses.

\section{Effects of $\mathrm{N}$ limitation and elevated $p \mathrm{CO}_{2}$ on elemental stoichiometry}

Under $\mathrm{N}$ limitation, species showed different trends in population densities and residual DIN concentrations in response to increasing $p \mathrm{CO}_{2}$. Population densities of $S$. trochoidea followed a bell-shaped pattern, indicating that intermediate $p \mathrm{CO}_{2}$ supported highest population densities in these $\mathrm{N}$ limited systems (Fig. 1A). Residual DIN concentrations showed highest values under elevated $p \mathrm{CO}_{2}$, suggesting highest efficiencies of DIN uptake under intermediate and low $p \mathrm{CO}_{2}$ (Fig. 1B). Cultures of $A$. fundyense were also sensitive to changes in $p \mathrm{CO}_{2}$ and became less dense under elevated $p \mathrm{CO}_{2}$, while residual DIN concentrations showed the inverse pattern with highest values under elevated $p \mathrm{CO}_{2}$ (Fig. 1). The observed $\mathrm{CO}_{2}$-dependent changes in POC:PON ratios (Table 2) were driven by species- 
specific alterations in either PON quotas alone $(S$. trochoidea) or both POC and PON quotas (A. fundyense).

Previous studies on dinoflagellates, including $A$. fundyense, have shown up to 2-fold higher POC quotas under N limitation (Leong \& Taguchi 2004, Fuentes-Grünewald et al. 2012). In our study, $A$. fundyense displayed no such effect (Table 2; Eberlein et al. 2014), which may be due to differences in culture conditions or species- and strain-specific regulation of enzymes involved in $\mathrm{C}$ storage under $\mathrm{N}$ limitation (Dagenais-Bellefeuille \& Morse 2013). The few studies on combined effects of $\mathrm{N}$ limitation and elevated $p \mathrm{CO}_{2}$ on marine phytoplankton do indeed show a high variety with respect to elemental quotas. In the coccolithophore Emiliania huxleyi, for instance, POC:PON ratios were higher under $\mathrm{N}$ limitation as compared to N-replete conditions, but remained similarly high (Müller et al. 2012, Rouco et al. 2013) or even decreased under elevated $p \mathrm{CO}_{2}$ (Sciandra et al. 2003), the latter reflecting a reduction in POC quotas. Besides strain-specific growth characteristics, these different responses may also have resulted from dissimilar growth conditions. In $\mathrm{N}$ limited cultures of the diatom Phaeodactylum tricornutum, POC:PON ratios increased with increasing $p \mathrm{CO}_{2}$ as a result of a relatively stronger increase in POC compared to PON quotas (Li et al. 2012).

According to our data, POC:PON ratios are particularly responsive to increasing $p \mathrm{CO}_{2}$ when limited by $\mathrm{N}$, which is in line with theory (Verspagen et al. 2014). Although the underlying responses in elemental composition were species-specific, we were able to link the $\mathrm{CO}_{2}$-dependent changes in PON quotas to shifts in $\mathrm{N}$ assimilation properties (see below), which may also apply to some of the observed responses in previous studies. In turn, changes in $\mathrm{N}$ assimilation properties can explain the observed shifts in residual DIN concentrations and population densities.

\section{Elevated $p \mathrm{CO}_{2}$ alleviates stress of $\mathrm{N}$ limitation}

For both species, PON quotas and residual DIN concentrations increased under elevated $p \mathrm{CO}_{2}$ (Fig. 1, Table 2). Irrespective of the $\mathrm{CO}_{2}$-dependent changes of these 2 measures, the relationship between the amount of $\mathrm{N}$ that can be incorporated by the cell and the amount of $\mathrm{N}$ that will remain in the medium reflects fundamental biochemical constrains of nutrient uptake in microalgae (Fersht 1974). It has been argued that under severe $\mathrm{N}$ limitation, the optimal strategy for a phytoplankton species is to reduce the number of uptake sites and to increase the number of active uptake areas per site, which will result in relatively low maximum uptake rates $\left(V_{\max }\right)$ with high substrate affinities (i.e. low half-saturation concentrations, $K_{1 / 2}$ ) (Litchman et al. 2007).

Using our residual DIN concentrations at the given growth rates (i.e. dilution rates) together with maximum growth rates under $\mathrm{N}$-replete conditions (Eq. 5), we estimated $K_{1 / 2}$ values (DIN) for growth and compared them with PON production rates from each experiment. The low $p \mathrm{CO}_{2}$ treatments showed low PON production rates combined with a low $K_{1 / 2}$ and confirmed the N-limitation strategy described by Litchman et al. (2007). Interestingly, under elevated $p \mathrm{CO}_{2}$, PON production rates and $K_{1 / 2}$ values simultaneously increased and showed a linear relationship (Fig. 5; S. trochoidea: $\mathrm{R}^{2}=0.701, \mathrm{n}=6, \mathrm{p}=0.038 ; A$. fundyense: $\mathrm{R}^{2}=0.837, \mathrm{n}=6, \mathrm{p}=0.011$ ). It thus seems that high $p \mathrm{CO}_{2}$ shifts $\mathrm{N}$ assimilation towards higher PON production rates and lower affinities, which could indicate that species suffer less from N limitation. Such $\mathrm{CO}_{2}$-dependent changes in $\mathrm{N}$ assimilation characteristics may also apply to other phytoplankton species. The coccolithophore E. huxleyi, for instance, also expressed higher PON production rates and residual DIN concentrations (which scale with a higher $K_{1 / 2}$ ) under elevated $p \mathrm{CO}_{2}$ (Müller et al. 2012). More experiments are needed, however, to verify whether this concept may be a general strategy and whether it can be attributed to $\mathrm{CO}_{2}$-dependent regulation in physiological key processes.

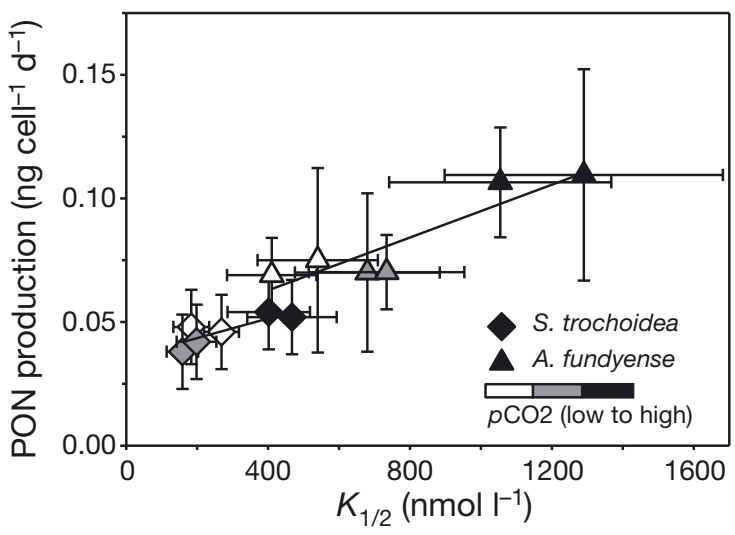

Fig. 5. Effect of elevated $p \mathrm{CO}_{2}$ on PON production rates versus half-saturation concentrations $\left(K_{1 / 2}\right)$ of growth for Scrippsiella trochoidea $(\bullet)$ and Alexandrium fundyense ( $(\boldsymbol{\Delta})$ under $\mathrm{N}$ limitation. Solid lines indicate significant trends and best fits from linear regression models $(S$. trochoidea: $\mathrm{R}^{2}=0.701, \mathrm{n}=6, \mathrm{p}=0.038 ;$ A. fundyense: $\mathrm{R}^{2}=0.837, \mathrm{n}=6$, $\mathrm{p}=0.011)$ 


\section{Reallocation of energy from CCM down-regulation}

The observed shifts in N-uptake characteristics towards higher PON production rates and lower affinities with elevated $p \mathrm{CO}_{2}$ could partly be explained by the reallocation of energy from downregulating CCMs. The majority of marine phytoplankton exhibit effective CCMs, which allow them to grow rather independently from $\mathrm{CO}_{2}$ availability (e.g. Rost et al. 2006, Fu et al. 2007, Ratti et al. 2007). This does not mean, however, that species do not benefit from increasing $\mathrm{CO}_{2}$ concentrations. In fact, increasing $\mathrm{CO}_{2}$ concentrations often lead to a downregulation of phytoplankton CCMs, thereby reducing the costs for acquiring inorganic $\mathrm{C}$ (Giordano et al. 2005).

In an earlier study, we showed that both dinoflagellate species $S$. trochoidea and $A$. fundyense possess an effective and adjustable CCM (Eberlein et al. 2014). Specifically, their overall $\mathrm{CO}_{2}$ affinity was 10 fold higher than would be expected from RuBisCO kinetics, and cells were able to take up $\mathrm{HCO}_{3}{ }^{-}$as their major $\mathrm{C}$ source. With respect to elevated $p \mathrm{CO}_{2}$, the relative $\mathrm{HCO}_{3}^{-}$uptake decreased for $S$. trochoidea, which may liberate energy for other processes (Eberlein et al. 2014). In A. fundyense, elevated $p \mathrm{CO}_{2}$ also caused a down-regulation of genes expressing carbonic anhydrase (CA) homologues (Van de Waal et al. 2014a), which is in line with frequently observed down-regulated CA activity under elevated $p \mathrm{CO}_{2}$.

It is conceivable that under $\mathrm{N}$ limitation, 'extra' energy resulting from the down-regulated CCM, as well as the shift in photosynthesis and respiration, may be reallocated to the uptake and assimilation of $\mathrm{N}$, especially since $\mathrm{N}$ assimilation also occurs mainly during the photoperiod (Paasche et al. 1984, Leong et al. 2010). Higher PON production rates under elevated $p \mathrm{CO}_{2}$ were also accompanied by higher quotas of N-rich compounds, such as chl $a$ and PSP toxins (Fig. 2, Table 2). Despite the apparent beneficial effect of elevated $p \mathrm{CO}_{2}$, the increased assimilation of $\mathrm{N}$ per cell was accompanied by a lowering of the affinity for DIN. Although we predicted the opposite pattern, i.e. increasing affinities for DIN under elevated $p \mathrm{CO}_{2}$, these results demonstrate a trade-off in $\mathrm{N}$ uptake between maximum PON production rates and affinities (Fig. 5). In a continuous culture system with a fixed dilution rate (i.e. a fixed supply rate of nutrients), such physiological changes may directly feed back on cellular growth as shown by the lower population densities under elevated $p \mathrm{CO}_{2}$ (Fig. 1A). These changes may affect the competitive success of both species, but aspects such as altered toxicity may also need to be considered when making predictions for the future ocean.

\section{PSP toxin content and composition in A. fundyense}

$\mathrm{N}$ limitation led to a strong change in PSP toxin content in A. fundyense. More specifically, under low $p \mathrm{CO}_{2}$, values were 4 -fold lower compared to those obtained under N-replete conditions (Fig. 2A). This observation reflects the dependency of N-rich PSP toxins on $\mathrm{N}$ availability and is in line with previous findings that show decreased PSP toxin contents under N limitation in various Alexandrium species (e.g. Boyer et al. 1987, Van de Waal et al. 2013). Interestingly, PSP toxin contents and the associated cellular toxicity increased with elevated $p \mathrm{CO}_{2}$ (Fig. 2). Starting from a minimum PSP toxin content of $\sim 5.5 \mathrm{pg} \mathrm{cell}{ }^{-1}$, values increased more than 8-fold and closely resembled the PSP toxin contents observed under N-replete and high $p \mathrm{CO}_{2}$ conditions. The associated increase in toxicity showed the same $\mathrm{CO}_{2}$ dependency and was no longer different to N-replete conditions above a $p \mathrm{CO}_{2}$ of 1000 patm (JohnsonNeyman: $\mathrm{p}>0.05)$. The $\mathrm{CO}_{2}$-dependent increase in PSP toxin contents correlated with the decrease in POC:PON ratios and was accompanied by an increase in PON quotas and PON production rates (Fig. 4, Table 2). Thus, the relatively higher $\mathrm{N}$ availability in the cells, as a result of down-regulated CCM, may explain the increased cellular PSP toxin content. Therefore, elevated $p \mathrm{CO}_{2}$ seems to not only alleviate the negative effects of $\mathrm{N}$ limitation on elemental quotas in general, but also to facilitate the synthesis of N-rich compounds such as PSP toxins (Fig. 4).

While there are, to our knowledge, no studies that have investigated the combined effects of elevated $p \mathrm{CO}_{2}$ and $\mathrm{N}$ limitation on PSP toxin production in the genus Alexandrium, there are several that have tested the effects of elevated $p \mathrm{CO}_{2}$. In 2 A. fundyense strains, for instance, PSP toxin content decreased under elevated $p \mathrm{CO}_{2}$ (Van de Waal et al. 2014a), whereas it remained relatively unaltered in some $A$. ostenfeldii strains (Kremp et al. 2012). In contrast, PSP toxin content in $A$. catenella increased under elevated $p \mathrm{CO}_{2}$ and further increased 10-fold when phosphorus (P) was limiting (Tatters et al. 2013). The relative availabilities of $\mathrm{N}$ and $\mathrm{P}$ have been shown to exert strong control on PSP toxin synthesis, which generally decreases under $\mathrm{N}$ limitation and increases under P limitation (e.g. Boyer et al. 1987, Cembella 
1998, Van de Waal et al. 2014b). Here, we demonstrate that the negative impact of $\mathrm{N}$ limitation on PSP toxin production is reduced under elevated $p \mathrm{CO}_{2}$.

Regarding toxin profiles of $A$. fundyense, contributions of the analogues $\mathrm{C} 1+\mathrm{C} 2, \mathrm{GTX} 2+3$, and NEO to total PSP toxin content remained largely unaltered in response to elevated $p \mathrm{CO}_{2}$ and $\mathrm{N}$ limitation (Fig. 3C-E). Interestingly, STX increased and GTX1+4 decreased with elevated $p \mathrm{CO}_{2}$, showing opposite trends than those observed under $\mathrm{N}$-replete conditions (Fig. 3A,B). Van de Waal et al. (2014a) argued that the observed down-regulation in sulfatases and up-regulation of sulfotransferases under elevated $p \mathrm{CO}_{2}$ could be a reason for the decrease in nonsulfated STX and the increase in mono-sulfated GTX1+4 under N-replete conditions. In view of our data, one could argue that $\mathrm{N}$ limitation may modulate the sulfur metabolism in the opposite direction. $\mathrm{CO}_{2}$ dependent changes have also been reported for other Alexandrium species. For instance, A. ostenfeldii showed increased STX under elevated $p \mathrm{CO}_{2}$ (Kremp et al. 2012), whereas A. catenella and A. fundyense (NPB8) displayed an increase in both STX and GTX1+4 under elevated $p \mathrm{CO}_{2}$ (Tatters et al. 2013, Hattenrath-Lehmann et al. 2015). Thus, PSP toxin composition by Alexandrium species lacks an unambiguous response to elevated $p \mathrm{CO}_{2}$. Further studies are required to understand the potential role of sulfur metabolism in synthesis of sulfonated PSP analogues.

These findings demonstrate that Alexandrium responds to elevated $p \mathrm{CO}_{2}$, and that these responses may be influenced by other co-occurring environmental changes. With an increasing number of reports on HAB events, there is a great need to improve our understanding of the impacts of global change on toxin synthesis (Fu et al. 2012). However, the increase in HAB reports may reflect, in part at least, a greater awareness of such blooms due to the increase in shellfish farming and the requirement for greater monitoring effort, as opposed to a major increase in such blooms per se (Hallegraeff 2010). With our data, we can clearly show that $\mathrm{N}$ availability may strongly modulate the responses in PSP toxin content to elevated $p \mathrm{CO}_{2}$. At the same time, however, the increase in toxin content under $\mathrm{N}$ limitation and elevated $p \mathrm{CO}_{2}$ was accompanied by a reduction in population densities (Fig. 1A). This implies that, under global change, the increase in PSP toxin quota or relative toxicity (Fig. 2) may be counteracted by a reduction in population densities. Obviously, the toxicity of natural Alexandrium blooms in a high- $\mathrm{CO}_{2}$ and nutrient-depleted ocean is also determined by other factors, including light and temperature. Multifactorial experiments are therefore needed to fully elucidate the impacts of global change on the quota and composition of PSP toxins.

\section{Ecological consequences}

The observed combined effects of elevated $p \mathrm{CO}_{2}$ and $\mathrm{N}$ limitation on cellular composition were accompanied by $\mathrm{CO}_{2}$-dependent changes in $\mathrm{N}$ assimilation. Together with other trade-offs (e.g. in C assimilation; Eberlein et al. 2014), these changes reflect important strategies of nutrient utilization and may ultimately have contributed to niche development. The potential of producing allelopathic compounds (Cembella 2003, John et al. 2015), being mixotrophic (Jeong et al. 2005), and motile (MacIntyre et al. 1997) further represents characteristic traits, which could explain why dinoflagellates thrive well in various environments. These traits may also allow species to temporarily avoid $\mathrm{N}$ limitation and prevent direct relationships between biomass build-up and inorganic nutrient availability, as assessed in this study. However, the presented insights into $\mathrm{N}$ and $\mathrm{C}$ assimilation under ocean acidification combined with $\mathrm{N}$ limitation demonstrate that interactions therein may influence, or even improve, certain trait values. The ability of both species to invest in 'biomass quality' under elevated $p \mathrm{CO}_{2}$ in combination with $\mathrm{N}$ limitation (i.e. lowered POC:PON ratios, higher chl $a$, and higher PSP toxin content in A. fundyense) may potentially optimize their persistence. Yet, the increase in biomass quality came at the expense of lower affinities for DIN (i.e. higher residual DIN concentrations) and subsequent lower population densities. According to theory, the residual amount of DIN in continuous culture experiments represents $R^{*}$, which is the lowest resource requirement for a species to maintain a stable population density at a given mortality or dilution rate (Tilman et al. 1982, Grover 1997). While elevated $p \mathrm{CO}_{2}$ may optimize species persistence under $\mathrm{N}$ limitation, the $\mathrm{CO}_{2}$-dependent increase in $R^{*}$ hints towards a lowered competitive ability for $\mathrm{N}$ assimilation. Whether ocean acidification turns out to be beneficial or detrimental under $\mathrm{N}$ limitation therefore depends on the ecological significance of the anticipated changes in species persistence and resource requirement. The interplay with additional traits such as allelopathy, mixotrophy, and vertical migration will further influence the success of the tested dinoflagellate species, with possible consequences for the viability and toxicity of their blooms. 
Acknowledgements. We thank Joaquin Baro (GEOMAR) for help with nutrient measurements and subsequent data analysis. We further acknowledge Nancy Kühne (Alfred Wegener Institute) for the assistance with toxin extraction and analysis. The work was funded by the European Community's Seventh Framework Programme (FP7/20072013)/ERC No. 205150 and the BIOACID II programme from the German Ministry of Education and Research.

\section{LITERATURE CITED}

Anderson DM, Glibert PM, Burkholder JM (2002) Harmful algal blooms and eutrophication: nutrient sources, composition, and consequences. Estuaries 25:704-726

Anderson DM, Alpermann TJ, Cembella AD, Collos Y, Masseret E, Montresor M (2012a) The globally distributed genus Alexandrium: multifaceted roles in marine ecosystems and impacts on human health. Harmful Algae 14:10-35

Anderson DM, Cembella AD, Hallegraeff GM (2012b) Progress in understanding harmful algal blooms: paradigm shifts and new technologies for research, monitoring, and management. Annu Rev Mar Sci 4:143-176

Badger MR, Andrews TJ, Whitney SM, Ludwig M, Yellowlees DC, Leggat W, Price GD (1998) The diversity and coevolution of RuBisCO, plastids, pyrenoids, and chloroplast-based $\mathrm{CO}_{2}$-concentrating mechanisms in algae. Can J Bot 76:1052-1071

Barlow RJ (1989) Statistics: a guide to the use of statistical methods in the physical sciences, Vol 29. John Wiley \& Sons, Chichester

> Behrenfeld MJ, O'Malley TR, Siegel DA, McClain CR and others (2006) Climate-driven trends in contemporary ocean productivity. Nature 444:752-755

- Beman JM, Chow CE, King AL, Feng Y and others (2011) Global declines in oceanic nitrification rates as a consequence of ocean acidification. Proc Natl Acad Sci USA 108:208-213

Boyer GL, Sullivan JJ, Anderson RJ, Harrison PJ, Taylor FJR (1987) Effects of nutrient limitation on toxin production and composition in the marine dinoflagellate Protogonyaulax tamarensis. Mar Biol 96:123-128

Brading P, Warner ME, Smith DJ, Suggett DJ (2013) Contrasting modes of inorganic carbon acquisition amongst Symbiodinium (Dinophyceae) phylotypes. New Phytol 200:432-442

Caldeira K, Wickett ME (2003) Anthropogenic carbon and ocean pH. Nature 425:365

Cembella AD (1998) Ecophysiology and metabolism of paralytic shellfish toxins in marine microalgae. In: Anderson DM, Cembella AD, Hallegraeff GM (eds) Physiological ecology of harmful algal blooms, Book G41. SpringerVerlag, Berlin, p 281-403

> Cembella AD (2003) Chemical ecology of eukaryotic microalgae in marine ecosystems. Phycologia 42:420-447

Collos Y, Vaquer A, Souchu P (2005) Acclimation of nitrate uptake by phytoplankton to high substrate levels. J Phycol 41:466-478

> Dagenais-Bellefeuille S, Morse D (2013) Putting the N in dinoflagellates. Front Microbiol 4:369

Dickson AG, Millero FJ (1987) A comparison of the equilibrium constants for the dissociation of carbonic acid in seawater media. Deep-Sea Res 34:1733-1743

Eberlein T, Van de Waal DB, Rost B (2014) Differential effects of ocean acidification on carbon acquisition in two bloom-forming dinoflagellate species. Physiol Plant 151: 468-479

Elser JJ, Bracken MES, Cleland EE, Gruner DS and others (2007) Global analysis of nitrogen and phosphorus limitation of primary producers in freshwater, marine and terrestrial ecosystems. Ecol Lett 10:1135-1142

> Feng Y, Warner ME, Zhang Y, Sun J, Fu FX, Hutchins DA (2008) Interactive effects of increased $p \mathrm{CO}_{2}$, temperature and irradiance on the marine coccolithophore Emiliania huxleyi (Prymnesiophyceae). Eur J Phycol 43: $87-98$

> Fersht AR (1974) Catalysis, binding and enzyme-substrate complementarity. Proc R Soc Lond B 187:397-407

> Fistarol GO, Legrand C, Rengefors K, Granéli E (2004) Temporary cyst formation in phytoplankton: a response to allelopathic competitors? Environ Microbiol 6:791-798

- Flynn KJ (1991) Algal carbon-nitrogen metabolism: a biochemical basis for modelling the interactions between nitrate and ammonium uptake. J Plankton Res 13: 373-387

> Fu FX, Warner ME, Zhang Y, Feng Y, Hutchins DA (2007) Effects of increased temperature and $\mathrm{CO}_{2}$ on photosynthesis, growth, and elemental ratios in marine Synechococcus and Prochlorococcus (cyanobacteria). J Phycol 43:485-496

> Fu FX, Zhang Y, Warner ME, Feng Y, Sun J, Hutchins DA (2008) A comparison of future increased $\mathrm{CO}_{2}$ and temperature effects on sympatric Heterosigma akashiwo and Prorocentrum minimum. Harmful Algae 7:76-90

Fu FX, Tatters AO, Hutchins DA (2012) Global change and the future of harmful algal blooms in the ocean. Mar Ecol Prog Ser 470:207-233

Fuentes-Grünewald C, Garcés E, Alacid E, Sampedro E, Rossi S, Camp J (2012) Improvement of lipid production in the marine strains Alexandrium minutum and Heterosigma akashiwo by utilizing abiotic parameters. J Ind Microbiol Biot 39:207-216

Gao K, Xu J, Gao G, Li Y and others (2013) Rising $\mathrm{CO}_{2}$ and increased light exposure synergistically reduce marine primary productivity. Nat Clim Change 2:519-523

> Giordano M, Beardall J, Raven JA (2005) $\mathrm{CO}_{2}$ concentrating mechanisms in algae: mechanisms, environmental modulation, and evolution. Annu Rev Plant Biol 56:99-131

Granéli E, Turner JT (2006) Ecology of harmful algae. Springer Verlag, Berlin

Grover JP (1997) Resource competition. Chapman \& Hall, London

Guillard RRL, Ryther JH (1962) Studies of marine planktonic diatoms: I. Cyclotella nana Hustedt, and Detonula confervacea Cleve. Can J Microbiol 8:229-239

Hallegraeff GM (2010) Ocean climate change, phytoplankton community responses, and harmful algal blooms: a formidable predictive challenge. J Phycol 46:220-235

Hattenrath-Lehmann TK, Smith JL, Wallace RB, Merlo LR and others (2015) The effects of elevated $\mathrm{CO}_{2}$ on the growth and toxicity of field populations and cultures of the saxitoxin-producing dinoflagellate, Alexandrium fundyense. Limnol Oceanogr 60:198-214

Hayes AF, Matthes J (2009) Computational procedures for probing interactions in OLS and logistic regression: SPSS and SAS implementations. Behav Res Meth 41:924-936

Hennon GMM, Quay P, Morales RL, Swanson LM, Armbrust EV (2014) Acclimation conditions modify physiological response of the diatom Thalassiosira pseudonana to ele- 
vated $\mathrm{CO}_{2}$ concentrations in a nitrate-limited chemostat. J Phycol 50:243-253

- Hutchins DA, Mulholland MR, Fu FX (2009) Nutrient cycles and marine microbes in a $\mathrm{CO}_{2}$-enriched ocean. Oceanography 22:128-145

IPCC (Intergovernmental Panel on Climate Change) (2013) Climate change 2013: the physical science basis. In: Stocker TF, Qin D, Plattner GK, Tignor $M$ and others (eds) Working Group 1 contribution to the Fifth Assessment Report of the Intergovernmental Panel on Climate Change. Cambridge University Press, Cambridge

$>$ Jeong HJ, Yoo YD, Park JY, Song JY and others (2005) Feeding by phototrophic red-tide dinoflagellates: five species newly revealed and six species previously known to be mixotrophic. Aquat Microb Ecol 40:133-150

John U, Litaker RW, Montresor M, Murray S, Brosnahan ML, Anderson DM (2014) Formal revision of the Alexandrium tamarense species complex (Dinophyceae) taxonomy: the introduction of five species with emphasis on molecular-based (rDNA) classification. Protist 165:779-804

John U, Tillmann U, Hülskötter J, Alpermann TJ, Wohlrab S, Van de Waal DB (2015) Intraspecific facilitation by allelochemical mediated grazing protection within a toxigenic dinoflagellate population. Proc R Soc Lond B 282: 20141268

Johnson PO, Neyman J (1936) Tests of certain linear hypotheses and their application to some educational problems. Stat Res Mem 1:57-93

Knap A, Michaels A, Close A, Ducklow H, Dickson AG (eds) (1996) Protocols for the Joint Global Ocean Flux Study (JGOFS) core measurements. JGOFS Report No. 19, IOC Manuals and Guides, UNESCO, Bergen

> Kremp A, Godhe A, Egardt J, Dupont S, Suikkanen S, Casabianca S, Penna A (2012) Intraspecific variability in the response of bloom-forming marine microalgae to changed climate conditions. Ecol Evol 2:1195-1207

Krock B, Seguel CG, Cembella AD (2007) Toxin profile of Alexandrium catenella from the Chilean coast as determined by liquid chromatography with fluorescence detection and liquid chromatography coupled with tandem mass spectrometry. Harmful Algae 6:734-744

> Leong SCY, Taguchi S (2004) Response of the dinoflagellate Alexandrium tamarense to a range of nitrogen sources and concentrations: growth rate, chemical carbon and nitrogen, and pigments. Hydrobiologia 515:215-224

> Leong SCY, Maekawa M, Taguchi S (2010) Carbon and nitrogen acquisition by the toxic dinoflagellate Alexandrium tamarense in response to different nitrogen sources and supply modes. Harmful Algae 9:48-58

> Li W, Gao K, Beardall J (2012) Interactive effects of ocean acidification and nitrogen-limitation on the diatom Phaeodactylum tricornutum. PLoS ONE 7:e51590

> Litchman E, Klausmeier CA, Schofield OM, Falkowski PG (2007) The role of functional traits and trade-offs in structuring phytoplankton communities: scaling from cellular to ecosystem level. Ecol Lett 10:1170-1181

MacIntyre JG, Cullen JJ, Cembella AD (1997) Vertical migration, nutrition and toxicity in the dinoflagellate Alexandrium tamarense. Mar Ecol Prog Ser 148:201-216

McCollin T, Lichtman D, Bresnan E, Berx B (2011) A study of phytoplankton communities along a hydrographic transect on the north east coast of Scotland. Marine Scotland Science Report 04/11, Marine Scotland, Aberdeen

- Mehrbach C, Culberson CH, Hawley JE, Pytkowicz RM (1973) Measurement of the apparent dissociation constants of carbonic acid in seawater at atmospheric pressure. Limnol Oceanogr 18:897-907

Melzner F, Thomsen J, Koeve W, Oschlies A and others (2013) Future ocean acidification will be amplified by hypoxia in coastal habitats. Mar Biol 160:1875-1888

Monod J (1949) The growth of bacterial cultures. Annu Rev Microbiol 3:371-394

> Moore CM, Mills MM, Arrigo KR, Berman-Frank I and others (2013) Processes and patterns of oceanic nutrient limitation. Nat Geosci 6:701-710

Morse D, Salois P, Markovic P, Hastings JW (1995) A nuclear-encoded form II RuBisCO in dinoflagellates. Science 268:1622-1624

Müller MN, Beaufort L, Bernard O, Pedrotti ML, Talec A, Sciandra A (2012) Influence of $\mathrm{CO}_{2}$ and nitrogen limitation on the coccolith volume of Emiliania huxleyi (Haptophyta). Biogeosciences 9:4155-4167

> Paasche E, Bryceson I, Tangen K (1984) Interspecific variation in dark nitrogen uptake by dinoflagellates. J Phycol 20:394-401

Patey MD, Rijkenberg MJA, Statham PJ, Mowlem M, Stinchcombe MC, Achterberg EP (2008) Determination of nitrate and phosphate in seawater at nanomolar concentrations. Trends Anal Chem 27:169-182

Pierrot DE, Lewis E, Wallace DWR (2006) MS Excel program developed for $\mathrm{CO}_{2}$ system calculations. Carbon Dioxide Information Analysis Center, Oak Ridge National Laboratory, Oak Ridge, TN. http://cdiac.ornl.gov/oceans/ co2rprt.html

Ratti S, Giordano M, Morse D (2007) $\mathrm{CO}_{2}$-concentrating mechanisms of the potentially toxic dinoflagellate Protoceratium reticulatum (Dinophyceae, Gonyaulacales). J Phycol 43:693-701

Rawlings JO, Pantula SG, Dickey DA (1998) Applied regression analysis, 2nd edn. Springer-Verlag, New York, NY

- Rokitta SD, Rost B (2012) Effects of $\mathrm{CO}_{2}$ and their modulation by light in the life-cycle stages of the coccolithophore Emiliania huxleyi. Limnol Oceanogr 57:607-618

Rost B, Riebesell U (2004) Coccolithophores and the biological pump: responses to environmental changes. In: Thierstein HR, Young JR (eds) Coccolithophores: from molecular processes to global impact. Springer, Berlin, p 99-125

Rost B, Richter KU, Riebesell U, Hansen PJ (2006) Inorganic carbon acquisition in red tide dinoflagellates. Plant Cell Environ 29:810-822

Rost B, Zondervan I, Wolf-Gladrow D (2008) Sensitivity of phytoplankton to future changes in ocean carbonate chemistry: current knowledge, contradictions and research directions. Mar Ecol Prog Ser 373:227-237

Rouco M, Branson O, Lebrato M, Iglesias-Rodríguez MD (2013) The effect of nitrate and phosphate availability on Emiliania huxleyi (NZEH) physiology under different $\mathrm{CO}_{2}$ scenarios. Front Microbiol 4:155

Sarmiento JL, Slater R, Barber R, Bopp L and others (2004) Response of ocean ecosystems to climate warming. Global Biogeochem Cycles 18:GB3003, doi:10.1029/ 2003GB002134

Sciandra A, Harlay J, Lefèvre D, Lemée R, Rimmelin P, Denis M, Gattuso JP (2003) Response of coccolithophorid Emiliania huxleyi to elevated partial pressure of $\mathrm{CO}_{2}$ under nitrogen limitation. Mar Ecol Prog Ser 261: $111-122$

Shimizu Y (1996) Microalgal metabolites: a new perspective. Annu Rev Microbiol 50:431-465 
Tatters AO, Flewelling LJ, Fu FX, Granholm AA, Hutchins DA (2013) High $\mathrm{CO}_{2}$ promotes the production of paralytic shellfish poisoning toxins by Alexandrium catenella from southern California waters. Harmful Algae 30: $37-43$

Tillmann U, Alpermann TL, da Purificacao RC, Krock B, Cembella AD (2009) Intra-population clonal variability in allelochemical potency of the toxigenic dinoflagellate Alexandrium tamarense. Harmful Algae 8:759-769

Tilman D, Kilham SS, Kilham P (1982) Phytoplankton community ecology: the role of limiting nutrients. Annu Rev Ecol Syst 13:349-372

Turpin DH (1991) Effects of inorganic $\mathrm{N}$ availability on algal photosynthesis and carbon metabolism. J Phycol 27: $14-20$

Van de Waal DB, Tillmann U, Zhu M, Koch BP, Rost B, John U (2013) Nutrient pulse induces dynamic changes in cellular C:N:P, amino acids, and paralytic shellfish poisoning toxins in Alexandrium tamarense. Mar Ecol Prog Ser 493:57-69

Van de Waal DB, Eberlein T, John U, Wohlrab S, Rost B

Editorial responsibility: Graham Savidge,

Portaferry, UK (2014a) Impact of elevated $p \mathrm{CO}_{2}$ on paralytic shellfish poisoning toxin content and composition in Alexandrium tamarense. Toxicon 78:58-67

> Van de Waal DB, Smith VH, Declerck SAJ, Stam ECM, Elser JJ (2014b) Stoichiometric regulation of phytoplankton toxins. Ecol Lett 17:736-742

Van de Waal DB, Eberlein T, Bublitz Y, John U, Rost B (2014c) Shake it easy: a gently mixed continuous culture system for dinoflagellates. J Plankton Res 36:889-894

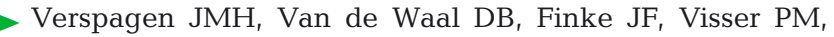
Huisman $\mathrm{J}$ (2014) Contrasting effects of rising $\mathrm{CO}_{2}$ on primary production and ecological stoichiometry at different nutrient levels. Ecol Lett 17:951-960

Wallace RB, Baumann H, Grear JS, Aller RC, Gobler CJ (2014) Coastal ocean acidification: the other eutrophication problem. Estuar Coast Shelf Sci 148:1-13

Wiese M, D'Agostino PM, Mihali TK, Moffitt MC, Neilan BA (2010) Neurotoxic alkaloids: saxitoxin and its analogs. Mar Drugs 8:2185-2211

> Wyatt T, Jenkinson IR (1997) Notes on Alexandrium population dynamics. J Plankton Res 19:551-575

Submitted: June 24, 2015; Accepted: November 20, 2015 Proofs received from author(s): January 12, 2016 